\title{
RANCANG BANGUN APLIKASI PENJUALAN TOKO BINTANG BANGUNAN KOTA DEPOK BERBASIS JAVA NETBEANS
}

\author{
Oktaviana Hafisya ${ }^{1}$, Yunita Endra Megiati ${ }^{2}$, Agung Ferdinan Sandy ${ }^{3}$ \\ ${ }^{1,2,3}$ Universitas Indraprasta PGRI \\ Jl. Raya Tengah No. 80, Kel. Gedong, Kec. Pasar Rebo, Jakarta Timur \\ 1fisya11okta@gmail.com, ${ }^{2}$ yunitaendra@gmail.com ${ }^{3}$ agungfsansdy@gmail.com
}

\begin{abstract}
ABSTRAK
Pada era teknologi dan informasi, sebuah teknologi yang handal dapat berperan penting dalam kemajuan bisnis suatu perusahaan. Toko Bintang Bangunan Kota Depok merupakan salah satu perusahaan yang menawarkan jasa dan barang untuk keperluan bahan bangunan. Namun, hingga saat ini perusahaan masih menggunakan sistem manual dalam pengolahan datanya, sehingga sering kali membuat pihak perusahaan kesulitan dalam mencari dan mengontrol barang-barang yang ada di gudang Hal ini juga mengakibatkan kerugian yang tidak terhitung dan tidak terduga bagi perusahaan. Berdasarkan permasalahan tersebut, maka perlu dirancang sebuah sistem aplikasi yang sesuai dan dibutuhkan oleh perusahaan. Tujuan dari penelitian ini adalah menganalisa sistem yang sedang berjalan pada toko Bintang Bangunan Kota Depok dan merancang sistem aplikasi bagi perusahaan. Pada penelitian ini, metode yang digunakan adalah metode Research and Development dan sistem waterfall untuk sistem pengembangannya. Sedangkan dalam pengumpulan data penelitian, dilakukan observasi langsung ke toko, wawancara kepada pihak terkait di toko. Hasil dari penelitian ini diperoleh suatu rancangan bangun aplikasi penjualan. Diterapkanya aplikasi ini dapat mempermudah karyawan dalam melakukan penjualan bahan bangunan. Penjualan bahan bangunan pada toko Bintang Bangunan Kota Depok menjadi lebih baik dan lebih terstruktur.
\end{abstract}

Kata Kunci: Aplikasi, Penjualan, Bahan Bangunan, Java.

\section{ABSTRACT}

In the era of technology and information, reliable technology can play an important role in a company's business. Toko Bintang Bangunan Depok City is one of the companies that offer services and goods for building materials. However, the company still uses a manual system in processing its data, so it often makes it difficult for the company to find and control the goods in the warehouse. So, the effect of this manual system results in countless and unexpected losses for the company. Based on these problems, it is necessary to design an application system that is appropriate and needed by the company. The purpose of this study is to analyze the system running at the Bintang Bangunan store in Depok City and design an application system for the company. In this study, the research and development method and the waterfall system for the development system using. Meanwhile, in collecting research data, direct observations make the store and interviews with related parties. The results of this research obtained a sales application design. The application of this application can make it easier for employees to sell building materials. Sales of building materials at Bintang Bangunan stores in Depok City are getting better and more structured..

Keyword: Applications, Sales, Building Materials, Java.

\section{PENDAHULUAN}

Pada era teknologi dan informasi, sebuah teknologi yang handal dapat memiliki peranan yang penting untuk kemajuan sebuah bisnis. Teknologi yang memberikanan informasi secara akurat dan tepat dapat menjadi sarana yang dapat meminimalisir waktu dan biaya. Sebagaimana lazimnya yang patut dilakukan oleh para pelaku bisnis (Subtabri 2012).

Toko Bintang Bangunan Kota Depok adalah salah satu perusahaan yang menawarkan jasa dan barang untuk keperluan bahan bangunan di toko Bintang Bangunan Kota Depok.
Namun perusahaan ini. hingga saat ini belum memiliki teknologi yang sekiranya diperlukan untuk membantu mengontrol datadata harian. Hal inilah yang membuat perusahaan kehilangan banyak data atas penjualan ataupun barang-barang yang berada pada stok gudang. Masih digunakannya sistem manual membuat datadata hilang.

Pihak perusahaan kebingungan dalam mencari dan mengontrol barang-barang yang ada di gudang sehingga barang tersebut dinyatakan hilang tanpa adanya bukti. Hal ini tidaklah efisien, dikarenakan memakan waktu 
lebih banyak, dan terkadang sering lupa mencatatkan data transaksi, sehingga data barang masuk dan barang yang terjual tidak sesuai. Hal ini menjadi kendala dalam pembuatan laporan transaksi nya. Permasalahan tersebut sering kali terjadi, sehingga dinilai tidak efektif di dalam pelayanan.(Prasetyo \& Dahlan, 2015) Tidak terintegrasinya sistem pencatatan manual dengan menggunakan banyak buku besar mengakibatkan kerugian yang tidak terhitung.

Masalah yang dihadapi saat penelitian ini dilakukan adalah ketika terjadi permintaan pasar yang tinggi sementara persediaan tidak tersedia di gudang dan ketika rendahnya permintaan pasar perusahan mampu mencegah terjadinya penumpukan barang digudang. (Veza, 2017) data penjualan, kontrol barang, data stok barang dan laporan yang ada. Melihat permasalahan tersebut maka dirancanglah sebuah sistem aplikasi penjualan bahan bangunan. Dengan adanya sistem aplikasi ini diharapkan tidak terjadi lagi kesalahan dalam perhitungan data, pencarian atau penelusuran data dan persediaan barang agar menjadi lebih mudah dan cepat Penelitian ini menggunakan pendekatan berorientasi objek dengan model proses pengembangan sistem prototipe.

Aplikasi sistem informasi persediaan dan penjualan barang dibuat dengan bahasa pemrograman java dengan database yaitu mysql. (Syahrul Mauluddin, 2018) Oleh karena itu, salah satu cara untuk mempermudah kegiatan pencatatan adalah dengan menggunakan sebuah aplikasi atau sistem. Berdasarkan uraian diatas maka peneliti tertarik untuk melakukan penelitian yang berjudul "Rancang Bangun Aplikasi Penjualan Toko Bintang Bangunan Kota Depok Berbasis Java Netbeans".

\section{METODE PENELITIAN}

Metode penelitian menjelaskan desain penelitian, rancangan kegiatan, ruang lingkup atau objek penelitian, tempat penelitian, teknik pengumpulan data, dan teknik analisis penelitian.

\section{Desain Penelitian}

Desain penelitian merupakan pedoman dalam melakukan proses penelitian diantaranya dalam menentukan instrumen pengambilan data, pengumpulan data serta analisa data. Dengan pemilihan desain penelitian yang tepat diharapkan akan dapat membantu peneliti dalam menjalankan penelitian secara benar. Tanpa desain yang benar seorang peneliti tidak akan dapat melakukan penelitian dengan baik karena tidak memiliki pedoman penelitian yang jelas. Metode penelitian menjelaskan desain penelitian, rancangan kegiatan ruang lingkup atau objek penelitian, tempat penelitian.

Desain penelitian memberikan prosedur untuk mendapatkan informasi yang diperlukan untuk menyusun atau menyelesaikan masalah dalam penelitian.

Desain penelitian merupakan dasar dalam melakukan penelitian.

\section{Metode Pegumpulan Data}

Penelitian ini dilaksanakan pada Bintang Bangunan Kota Depok. Metode pengumpulan data yang digunakan dalam rancang bangun penjualan bahan bangunan ini adalah:

1. Wawancara

Penulis melakukan wawancara dengan pemilik toko Bintang Bangunan Kota Depok yaitu Bapak Mustofa Kamil, untuk membahas mengenai bagaimana proses penjualan dan pembelian bahan bangunan dan apa saja kendala dalam pengolahan data.

2. Observasi

Observasi ini dilaksanakan di Toko Bintang Bangunan Kota Depok pada bulan Maret 2021. Observasi yaitu metode untuk mendapatkan data dengan melakukan pengamatan langsung, pencatatan, dan pengumpulan data-data yang dilakukan pada Toko Bintang Bangunan Kota Depok. Observasi yang dilakukan adalah mempelajari dan mengamati sistem kerja yang berjalan sebelumnya dimana cara kerja sistem lama tersebut masih menggunakan sistem manual.

3. Dokumentasi

Metode dokumentasi ini digunakan untuk mendapatkan berbagai informasi dari toko Bintang Bangunan Kota Depok, dengan cara melihat dan mencatat data yang diperlukan dalam penelitian. 


\section{Teknik Analisis Penelitian}

Analisis penelitian yang dilakukan adalah metode analisa Research and Development dan sistem Waterfall untuk sistem pengembangannya. Menurut (Sugiyono 2016), "Metode penelitian dan pengembangan atau dalam inggrisnya Research and Development adalah metode penelitian yang digunakan untuk menghasilkan produk tertentu, dan menguji keefektifan produk tersebut".

Sedangkan metode Waterfall adalah metode pengembangan perangkat lunak yang memungkinkan pembuatan sistem dilakukan secara terstuktur dan sistematis (berurutan) sesuai dengan siklus pengembangan yang ada. Metode ini disebut waterfall atau air terjun karena dalam prosesnya, sistem akan dibuat berurutan setahap demi setahap. Dalam metode ini. Jika tahapan 1 belum selesai, maka tahapan 2 tidak bisa berjalan, begitupun seterusnya. Semua tahapan saling berkaitan dan masing-masing harus dikerjakan secara detail dan terdokumentasi, diharapkan sehingga dapat memberikan informasi dan dapat ditarik kesimpulan yang lebih luas.

\section{HASIL DAN PEMBAHASAN}

Dari hasil penelitian yang penulis lakukan maka penulis dapat menganalisa permasalahan yang ada pada sistem penjualan bahan bangunan di Bintang Bangunan Kota Depok yaitu:

1. Input data penjualan dan pembelian bahan bangunan masih menggunakan sistem manual membuat data-data penjualan dan pembelian tidak tersusun rapi dan bahkan hilang.

2. Tidak adanya sebuah sistem yang memberikan laporan bulanan menyebabkan perusahaan tidak dapat mengontrol pengeluaran dan data stok barang yang ada, dan tidak tersusunnya sistem pencatatan manual dengan menggunakan banyak buku besar mengakibatkan kerugian yang tidak terhitung dan tidak terduga.

3. Pembuatan laporan masih manual, dan membutuhkan banyak waktu sehingga tidak efisien dan tidak tersusun sehingga data tidak akurat.
4. Tidak terintegrasi dan memakan waktu yang lama untuk pengontrolan data-data barang dan laporan.

Berdasarkan masalah-masalah yang terjadi di Bintang Bangunan Kota Depok, maka penulis memberikan alternatif penyelesaian masalah yaitu:

1. Sistem aplikasi menggunakan bahasa pemograman Basis Java dan menggunakan database MySQL.

2. Aplikasi penjualan bahan bangunan ini merupakan sistem aplikasi penjualan yang

3. dapat membantu administrasi penjualan toko bangunan, persedian barang, dan laporan.

\section{Diagram konteks sistem yang diusulkan}

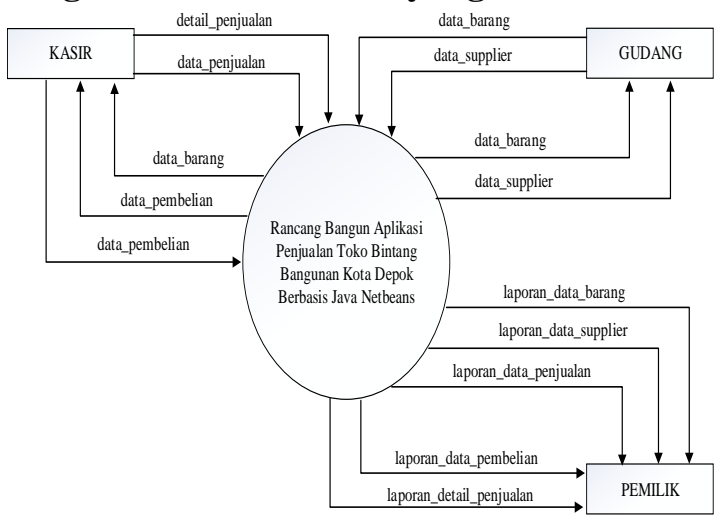

Gambar 1. Diagram Konteks yang Diusulkan

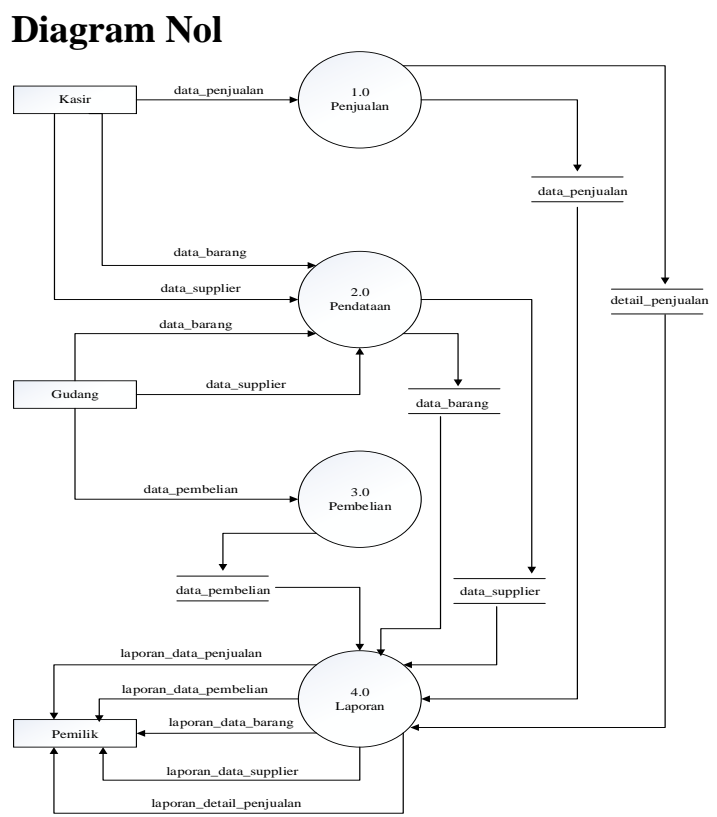

Gambar 2. Diagram Nol yang Diusulkan 
Normalisasi

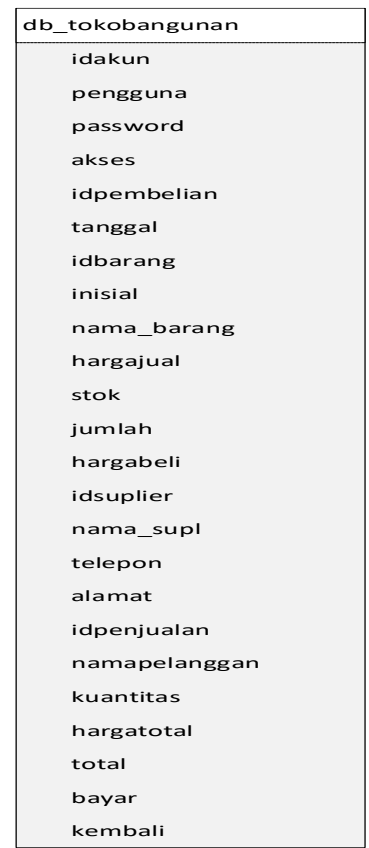

Gambar 3. Normalisasi Bentuk Tidak Normal

\section{ERD (Entity Relationship Diagram)}

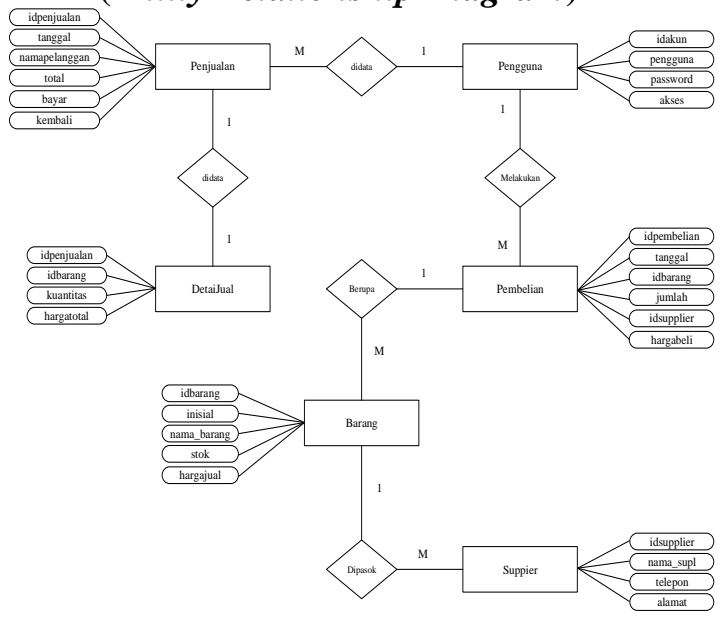

Gambar 4. Entity Relationship Diagram

\section{Tampilan Layar Aplikasi Penjualan Bahan Bangunan}

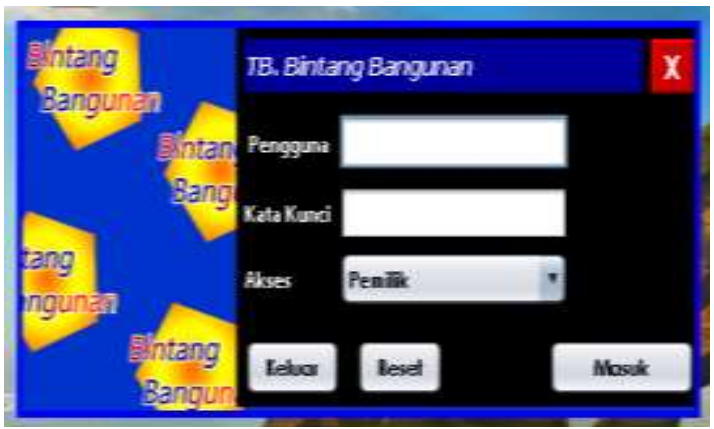

Gambar 5. Tampilan menu Login

Tampilan login muncul pada awal program dijalankan. Pengguna dihadapkan pada kotak dialog untuk memasukan pengguna dan kata kunci yang dimiliki oleh masing-masing pengguna hak akses. Jika pengguna, kata kunci dan hak akses yang sesuai maka tampilan akan masuk ke menu utama.

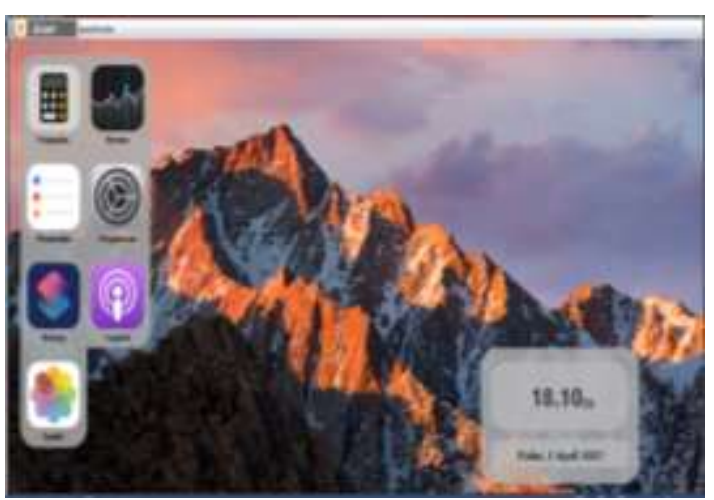

Gambar 6. Tampilan Menu Utama

Tampilan menu utama terdapat beberapa menu diantaranya menu penjualan, pembelian, data barang, data Supplier, review dan pengaturan. Pada menu utama juga terdapat informasi waktu.

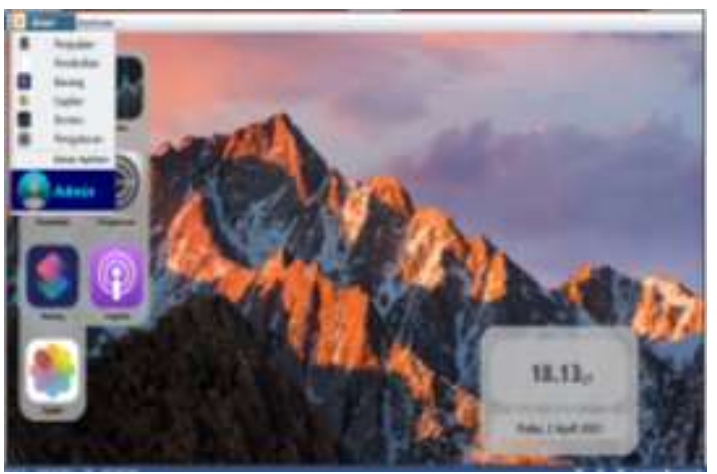

Gambar 7. Tampilan Menu Start

Tampilan menu start sama seperti tampilan menu utama terdapat beberapa menu diantaranya menu penjualan, pembelian, data barang, data Supplier, review dan pengaturan.

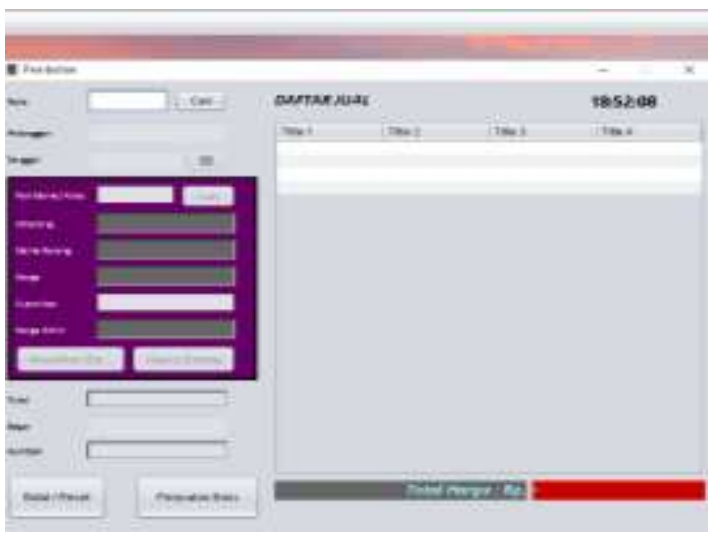

Gambar 8. Tampilan Menu Penjualan 
Pada tampilan form penjualan, terdapat informasi data penjualan. Data penjualan dapat diinput dan diubah oleh bagian kasir.

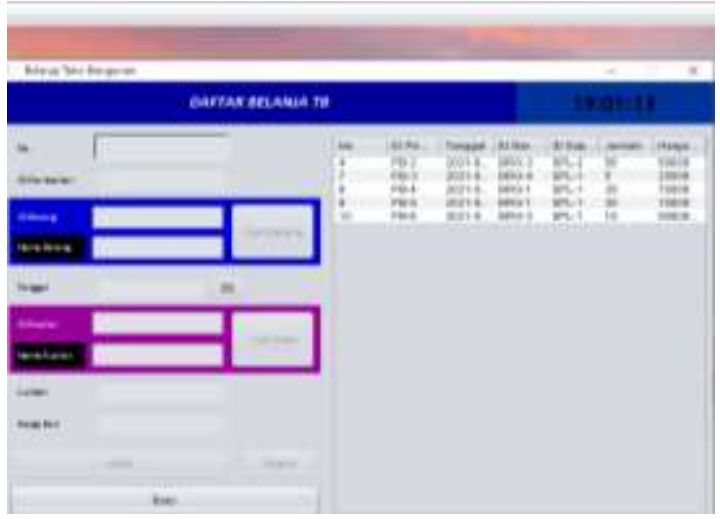

Gambar 9. Tampilan Menu Pembelian

Pada tampilan form pembelian, terdapat informasi data pembelian. Data pembelian dapat diinput dan diubah oleh bagian kasir dan gudang.

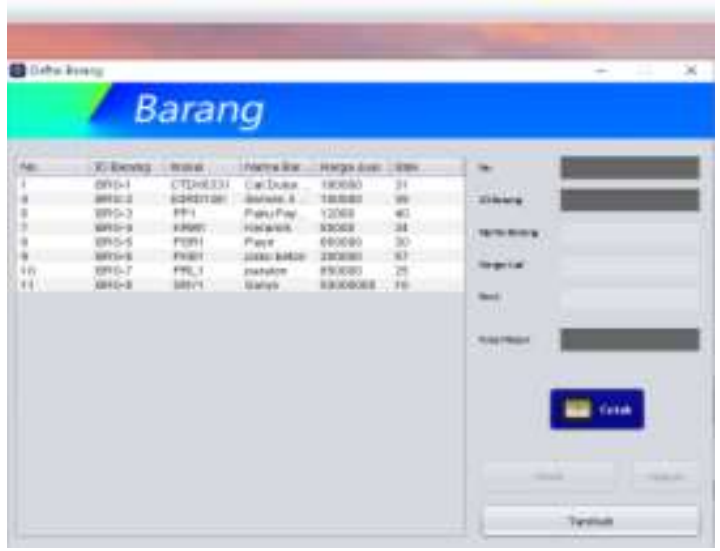

Gambar 10. Tampilan Menu Data Barang

Pada tampilan form data barang, terdapat informasi data barang. Data barang dapat diinput dan diubah oleh bagian kasir dan gudang.

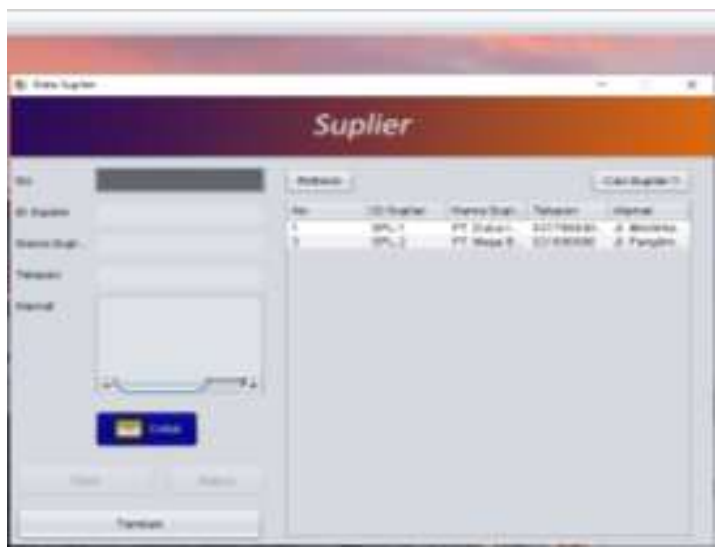

Gambar 11. Tampilan Menu Data Supplier
Pada tampilan form data Supplier, terdapat informasi data Supplier. Data Supplier dapat diinput dan diubah oleh bagian gudang.

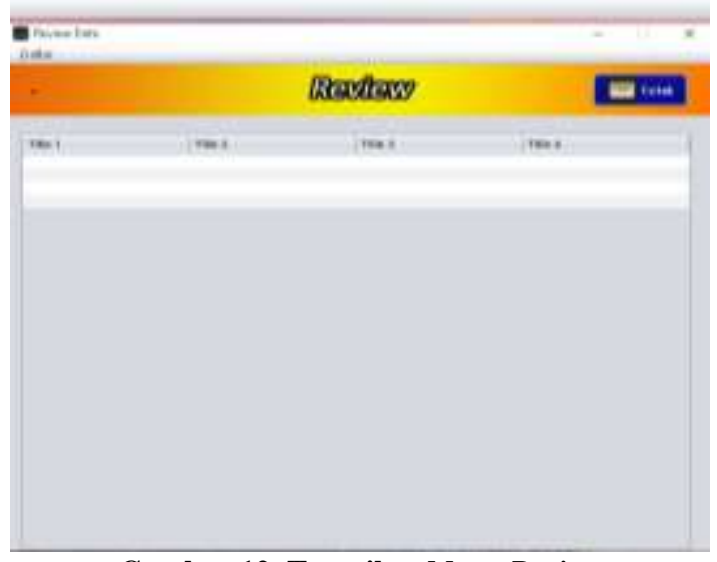

Gambar 12. Tampilan Menu Review

Pada tampilan form review, terdapat semua informasi laporan. Dan dapat di lihat oleh pemilik, kasir dan bagian gudang.

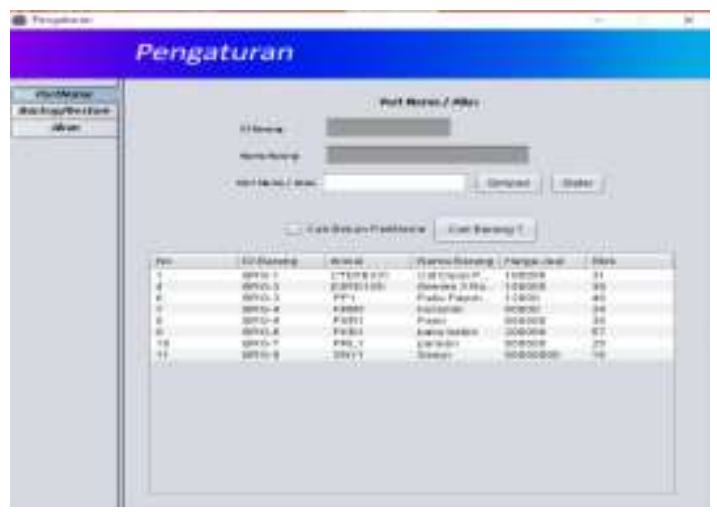

Gambar 13. Tampilan Pengaturan Partname

Pada tampilan form pengaturan PartName, terdapat informasi data PartName. Data PartName dapat diinput oleh pemilik dan bagian kasir.

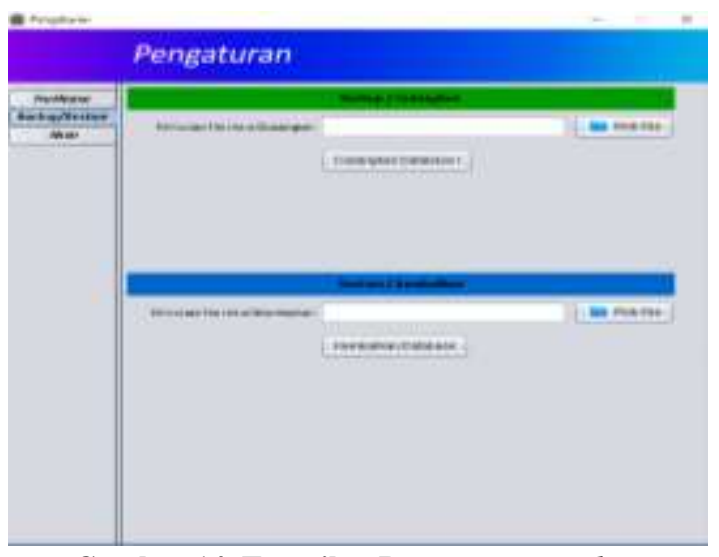

Gambar 14. Tampilan Pengaturan Backup 
Pada tampilan form pengaturan Backup/Restore, terdapat informasi data untuk mebackup atau merestore data. Data Backup/Restore dapat oleh pemilik, bagian kasir dan bagian gudang.

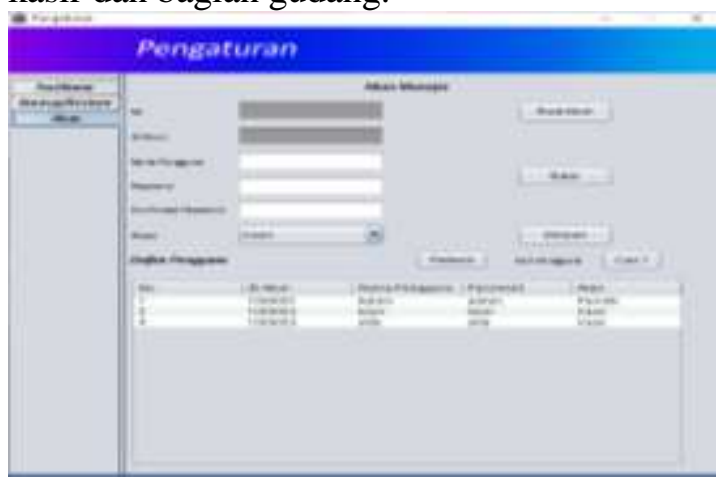

Gambar 15. Tampilan Pengaturan Akun

Pada tampilan form pengaturan akun, terdapat informasi semua data akun. Data akun dapat diinput dan diubah oleh pemilik.

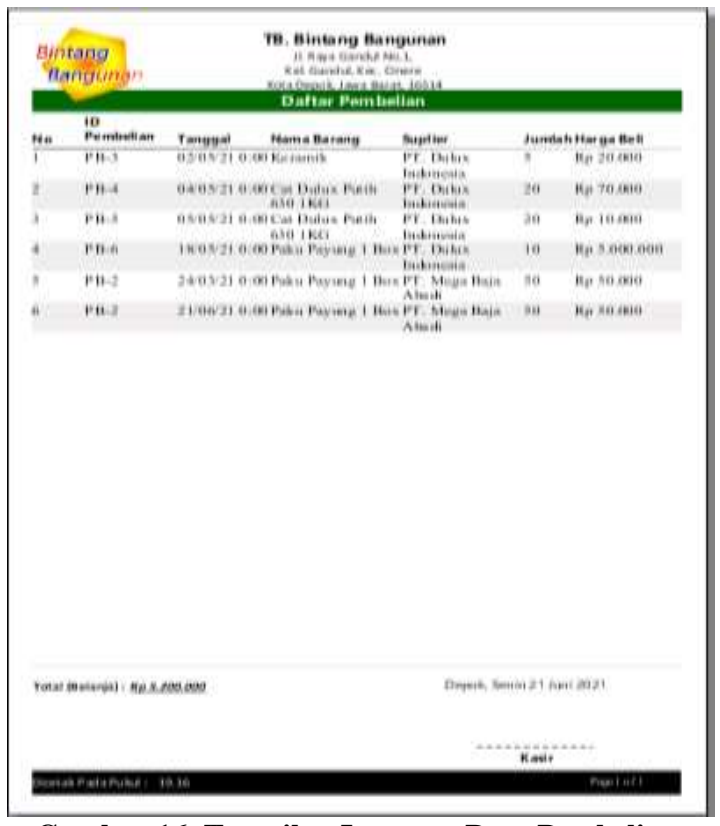

Gambar 16. Tampilan Laporan Data Pembelian

Tampilan laporan data pembelian berisikan data pembelian yang telah dimasukan sebelumnya ke database. Selanjutnya laporan data pembelian tersebut di cetak dan diberikan kepada pemilik toko Bintang Bangunan.

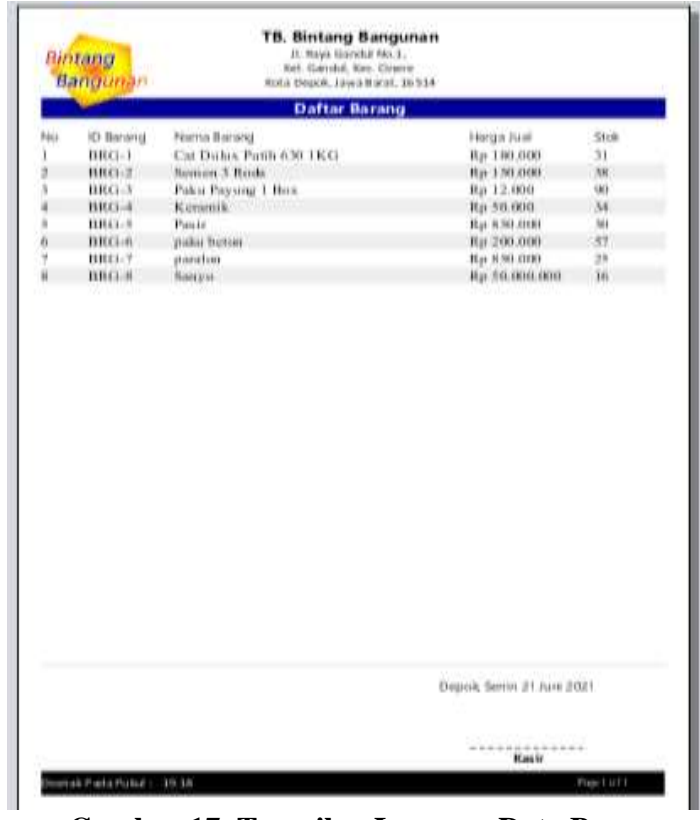

Gambar 17. Tampilan Laporan Data Barang

Tampilan laporan data barang berisikan data barang yang telah dimasukan sebelumnya ke dalam database. Selanjutnya laporan data barang tersebut dicetak dan diberikan kepada pemilik toko Bintang Bangunan.

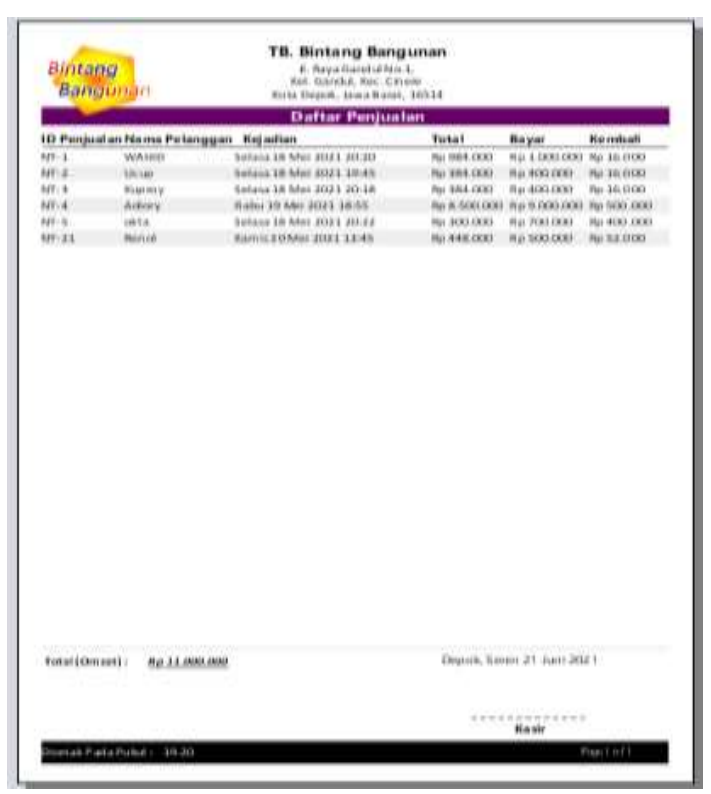

Gambar 18. Tampilan Laporan Data Penjualan

Tampilan laporan data penjualan berisikan data penjualan yang telah melakukan transaksi penjualan dan di simpan kedalam database. Selanjutnya laporan data penjualan tersebut dicetak dan di berikan kepada pemilik toko Bintang Bangunan. 


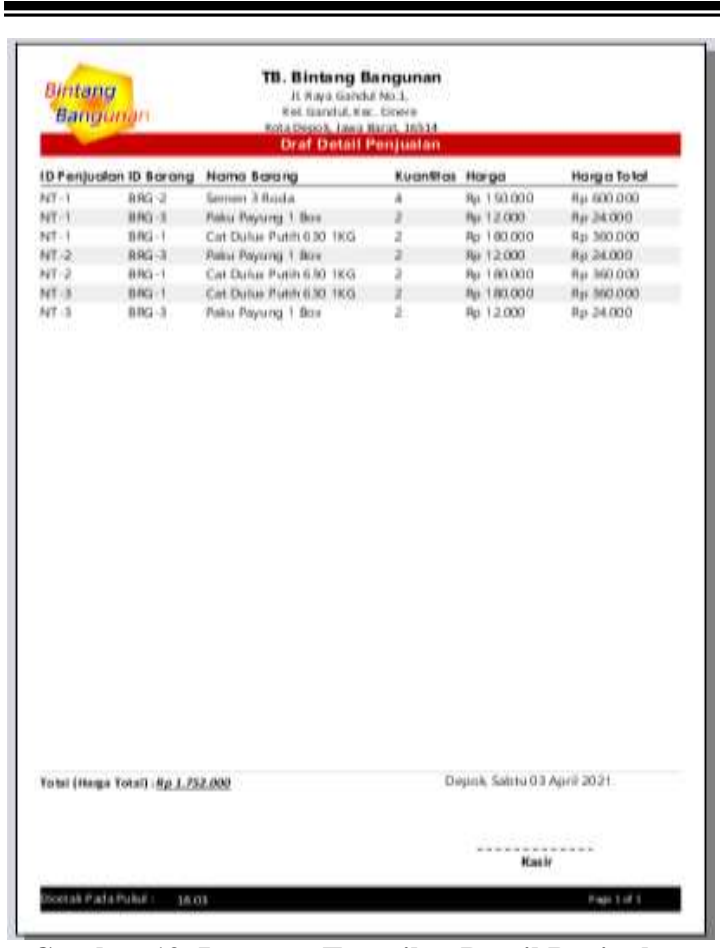

Gambar 19. Laporan Tampilan Detail Penjualan

Tampilan laporan detail penjualan berisikan detail penjualan yang telah melakukan transaksi penjualan dan detail penjualan di simpan kedalam database. Selanjutnya laporan detail penjualan tersebut dicetak dan di berikan kepada pemilik toko Bintang Bangunan.

Tampilan laporan detail penjualan berisikan detail penjualan yang telah melakukan transaksi penjualan dan detail penjualan di simpan kedalam database. Selanjutnya laporan detail penjualan tersebut dicetak dan di berikan kepada pemilik toko Bintang Bangunan.

\section{SIMPULAN DAN SARAN}

Berdasarkan hasil dan pembahasan dapat disimpulkan bahwa rancangan aplikasi penjualan bahan bangunan telah dibuat dengan menggunakan bahasa pemrograman Java Netbeans serta database MySQL dengan software XAMPP. Penerapan aplikasi ini dapat mempermudah karyawan dalam melakukan penjualan bahan bangunan. Penjualan bahan bangunan pada toko Bintang Bangunan Kota Depok menjadi lebih baik dan lebih terstruktur.

Sebagai saran untuk mengembangkan penelitian ini adalah agar memeriksa kembali kelemahan-kelemahan sistem yang dibuat sehingga dapat dilakukan perbaikan dalam merancang sistem penjualan bahan bangunan berikutnya. Admin adalah pihak yang terlibat langsung di dalam penggunaan sistem ini, oleh karena itu disarankan sebelum sistem ini digunakan, admin diberikan pelatihan dan penjelasan mengenai proses kerja sistem yang akan diterapkan.

\section{DAFTAR PUSTAKA}

Sugiyono. 2016. "Metode Penelitian dan Pengembangan (Research and Development/R\&D)." Bandung: Alfabeta, 334.

Sutabri, Tata. 2012. "Konsep Sistem Informasi." Jurnal Administrasi Pendidikan UPI 3 (1): 248.

Prasetyo, D., \& Dahlan, A. (2015). Pembuatan Aplikasi Pengolahan Data Transaksi Dan Penjualan Aksesoris Handphone Pada Toko Yoyo' Cell. Data Manajemen Dan Teknologi Informasi (DASI), 16(1), 30.

Syahrul Mauluddin, N. S. (2018). Sistem Informasi Persediaan Dan Penjualan Barang Berbasis Desktop Di D-Net House. Prosiding Seminar Nasional Teknik, Komputer Dan Rekayasa (SAINTIKS), October, III-12.

Veza, O. (2017). Perancangan Sistem Informasi Inventory Data Barang Pada Pt.Andalas Berlian Motors (Studi Kasus: PT Andalas Berlian Motors Bukit Tinggi). Jurnal Teknik Ibnu Sina (JT-IBSI), 2(2), 121-134. https://doi.org/10.36352/jt-ibsi.v2i2.63 